\title{
ЧЕХОВСКИЙ САХАЯИН: ОПЫТЫ ФОТОГРАФИЧЕСКОЙ ФИКСАЦИИ ОСТРОВА
}

\author{
Е. В. Головнева \\ Уральский федеральный университет \\ имени первого Президента России Б. Н. Ельцина, Екатеринбург, Россия \\ golovneva.elena@gmail.com
}

И. А. Годовнев

Музей антропологии и этнографии имени Петра Великого (Кунсткамера) РАН,

Санкт-Петербург, Россия

golovnev.ivan@gmail.com

Статья подготовлена в рамках исполнения проекта

«Опыты изучения и визуальной репрезентации фронтирных территорий

России и СССР в визуальной антропологии первой половины XX века:

на примере исследований российских и венгерских учёных

и кинематографистов» при поддержке Российского фонда

фундаментальных исследований (проект № 18-59-23007)

В статье исследуются фотографические репрезентации Сахалина в конце XIX века, в период пребывания на острове писателя А. П. Чехова. Сахалин рассматривается как особое культурно-географическое пространство с выраженными фронтирными чертами. Отмечается, что особенности сахалинской региональной идентичности выстраивались на основе идей «отдалённого острова-материка» и «места невыносимых страданий». Рассматривая место Сахалина в «имперском воображении», авторы обращаются к опытам фотофиксации острова в указанный период. В методологическом отношении анализ чеховской фотоколлекции о Сахалине рассматривается в русле современных фронтирных, метонимических и визуальноантропологических исследований. В качестве эмпирического материала в тексте используются материалы Архива Общества изучения Амурского Края (г. Владивосток), а также фотоснимки Сахалина конца XIX века, входящие в альбом польского исследователя Б. И. Дыбовского (1833-1930) и хранящиеся в настоящее время в Камчатском краевом объединённом музее города Петропавловска-Камчатского. Развивая дискурс о фотографии как значимом способе визуальной репрезентации фронтирных территорий России, авторы предлагают систематизацию и классификацию основных сюжетов фотоснимков о Сахалине (на примере деятельности фотографа И. И. Павловского), осуществляют корреляцию фотографических и литературных образов, выявляют роль фотоснимков в формировании представлений о Сахалине внутри империи и за её пределами. В статье отмечается, что в фотографии визуальные критерии жизни на «каторж- 
ном острове» создавадись посредством фиксации типических персонажных позиций и жанровых сцен (труд и быт каторжан), физической антропологии («инородческие лица», «лица преступников»), архитектурного и природного ландшафта острова, определялись режимом просмотра «картинки» или фотоальбома. Авторы приходят к выводу, что фотоснимки чеховского Сахалина, наряду с литературными опытами конца XIX века, проводили зримые границы между населением острова и остальной Россией и, зафиксировав их, утверждали наличие у сахалинского сообщества стабильных отличительных признаков.

Ключевые слова: фотография, фронтир, Сахалин, Российская империя, визуализация, конструирование образа региона, литература XIX века, А. П. Чехов, И. И. Павдовский.

\title{
CHEKHOV'S SAKHALIN: PHOTOGRAPHIC FIXATION OF THE ISLAND
}

\author{
Elena Golovneva \\ Ural Federal University named after the First President of Russia B. N. Yeltsin, \\ Yekaterinburg, Russia \\ golovneva.elena@gmail.com
}

\section{Ivan Golovnev}

Peter the Great Museum of Anthropology and Ethnography (the Kunstkamera) of the Russian Academy of Science, Saint-Petersburg, Russia golovnev.ivan@gmail.com

The article examines the photographic representations of Sakhalin in the end of XIX century, in the period of A. P. Chekhov's stay on the island. Sakhalin is viewed as a peculiar cultural and geographical space with clear frontier characteristics. Sakhalin regional identity is seen as formed on the basis of ideas of "the remote island - continent" and "the place of nameless misery". Beginning with an analysis of Sakhalin in the context of imperial imagination, authors rediscover a photofixation of the island in the above-mentioned period. Analysis of Chekhov's photo collection is addressed to the works of frontier and memory studies as well as visual anthropology. The article is based on empirical data of Archive of Amur region Research Society (Vladivostok) and photos from Benedict Dybovsky's (1833-1930) album that is stored in Kamchatka Regional United Museum (Petropavlovsk-Kamchatsky). Developing a discourse about photography as a valuable resource for visual representation of the frontier territories, the authors give systematization and classification of the main images of Sakhalin at the end of XIX century (a case of 
photographer I. I. Pavlovsky), present the correlation between photographic and literary images as well as reveal the role of those photos in perception of Sakhalin inside and outside of an empire. The article argued that visual criteria of Sakhalin's life were created by means of typical protagonist's positions and scenes (labor and everyday life of hard laborers), physical anthropology (indigenous faces, faces of criminals), architect and natural landscape of the island. The authors came to the conclusion that photos of Sakhalin as well as literary works on the island depict the visible margins between Sakhalin and other parts of Russia and present the specifics of Sakhalin regional identity.

Keywords: photography, frontier, Sakhalin, Russian Empire, visualization, constructing the image of region, XIX century literature, Anton Chekhov, Innokentii Pavlovsky.

DOI 10.23951/2312-7899-2020-1-76-92

Визуальное нуждается в вербальной поддержке, а вербальная коммуникация - в визуальном опосредовании.

Kimitaka Matsuzato

Согласно конструктивистскому подходу к изучению регионов [Головнева 2018, 6], чтобы обрести реальность и порождать идентичности, дюбой регион должен быть видимым и показываемым не только посредством научной и художественной дитературы, но и визуально-антропологическим способом: в рисунках, чертежах, фотографиях, кинематографе.

Окраинные территории Российской империи до сих пор слабо изучены с точки зрения их визуадизации, поскольку, по словам Е.А. Вишленковой, «в российской историографии за Российской империей утвердился статус пространства письменной культуры, в котором визуальное устойчиво воспринимается как вторичное. В результате этого до последнего времени исследователи, работающие с симводическим миром Российской империи, рассматривади визуальные репрезентации дибо как илдюстрацию письменного текста, либо как специфическую упаковку для артикулированных идей» [Вишленкова 2011, 4]. Данное обстоятельство со всей очевидностью открывает необходимость выявдения и анадиза примеров визуализации многоликости Российской империи в изучении её отдалённых регионов, что лежит в основании понимания гетероген- 
ности и связности жанра визуальных путешествий как таковых [Смирнов 2017, 10].

В предлагаемой работе анализируется пока ещё слабоосмысленный опыт визуального описания фронтирных территорий Российской империи - фотографические репрезентации Сахалина в конце XIX века (в период пребывания на острове писателя А. П. Чехова), предлагается их систематизация и классификация, выявдяется роль данных фотоснимков в формировании представлений о Сахалине в указанный период. В методологическом отношении анадиз фотоколлекции о Сахалине рассматривается в русле современных фронтирных, метонимических и визуально-антропологических исследований [Cosgrove 2008; Kivelson, Neuberger 2008; Osborne 2000]. В качестве эмпирического материала в тексте используются фотографии Архива Общества изучения Амурского края (г. Владивосток), а также снимки Сахалина конца XIX века, входящие в альбом польского исследователя Б. И. Дыбовского (1833-1930) и хранящиеся в настоящее время в Камчатском краевом объединённом музее г. Петропавловска-Камчатского. Данные материалы были получены авторами работы в ходе проведения архивных исследований летом 2017 и 2018 гг.

\section{Отдадённый остров-материк и «место невыносимых страданий»}

Одно из самых удалённых от центра пространство Российской империи - Дальний Восток в конце XIX - начале XX века в российском общественном сознании, безусловно, выступал как terra incognita. Это являлось следствием прежде всего географического положения «этой страны» - на краю Азиатского материка, с одной стороны которого находилась большая площадь суши, а с другой громадное водное пространство Великого океана. В 1920-х гг. русский путешественник и исследователь дальневосточного края В. К. Арсеньев отмечал, что в исследовательском отношении всю территорию Дальневосточного региона можно разделить так: детальная исследованность - 10 \%, поверхностная - $60 \%$, районы, совершенно не изученные даже в географическом отношении, - 30 \% [Арсеньев 1920, 3-4]. При отсутствии грамотной и планомерной колонизации края на Дальний Восток часто смотрели как на «бесполезную колонию» [Арсеньев 1926, 1], в которой возникла сложная ситуация, когда «корейцы взяли в свои руки весь береговой каботаж 
Японского моря, японцы решили хозяйничать у берегов Сахалина и в Охотском море, а американцы удоводьствовались Беринговым морем, сибирским побережьем Дедовитого океана» [Там же]. Неудивительно, что, находясь на пересечении раздичных культур, в зоне активного взаимодействия российской и восточноазиатской цивилизации (Китай, Корея, Япония), Дальний Восток в это время привлекал к себе особое внимание не тодько российского правительства, но и через путешествия многочисленных отечественных и зарубежных исследователей, учёных, художников-рисовадьщиков, а с появлением фотодела - фотографов. В «растяжении имперского воображения современников эти акторы играли особую роль» [Jay 1988, 19-20].

Конец XIX - начало XX века - это время пробуждения интереса русских путешественников к одной из самых примечательных дадьневосточных территорий - Сахадину. Остров Сахалин, согласно русско-японским договорам и соглашениям 1855 г., стал принадлежать обеим странам на правах общего владения, а в 1875 г. по Санкт-Петербургскому договору был объявлен собственностью России. Предпринимаемые в конце XIX - начале XX века учёными, писателями, журналистами путешествия на остров Сахалин следует рассматривать как важный способ «симводического освоения» дальневосточных территорий, при котором Сахалин органично включается в область «воображаемого» о Дальнем Востоке. Дитературные и фотографические репрезентации Сахалина, появившиеся в рассматриваемый период, представдяют собой важный этап в познании российского дальневосточного фронтира, а сахалинская тематика присутствует на страницах многих работ конца XIX века, посвящённых социально-экономическому развитию России. Очевидно, что путешествия на Сахалин, предпринимаемые в тот период, позводяли не только фиксировать объективное и беспристрастное видение действительности, но и становились значимым историческим свидетельством природных и культурных особенностей острова, а также визионерским средством, помогающим планировать и прогнозировать жизнь на «краю света» во всех её проявлениях, служащим основой для понимания «пространственного поведения дюдей и принятия ими решений» [Kearney, Kaplan 1997, 580].

При географическом описании Сахалина многие исследователи обращали внимание на то, что очертания острова напоминают очертания рыбы, лежащей на боку и вытянутой в меридиональном направдении, голова которой обращена к Охотскому морю, а хвост - к Японии. В метагеографическом смысле Сахалин вос- 
принимался в конце XIX века (и воспринимается сейчас) как край мира, замкнутое пространство, отдалённый остров-материк, имеющий важное военно-стратегическое значение, с мощной внутренней социокультурной энергетикой. Действительно, в географическом плане от материка остров отделяется Татарским проливом Японского моря, проливом Невельского, Амурским лиманом и Сахалинским заливом, а от о. Хоккайдо - продивом Лаперуза. Таким образом, Сахалин является островной территорией не только с точки зрения экономической и социальной географии, а прежде всего с точки зрения физической.

Крайне удалённый от центральной части России, Сахалин как культурно-антропологическое пространство характеризуется фронтирными чертами: первозданной, «грозной» природой, «во взаимодействии с которой, без человеческого присутствия, можно проводить целые дни» [Graybill 2013, 6], окраинным расположением, проектизмом, военной экспансией, высоким сосредоточением преступного элемента и этнокультурной неоднородностью ${ }^{1}$. Вполне закономерно, что со временем здесь возникла и особая форма региональной идентичности - сахалинская (сахалинцьь, люди Сахалинa) [Graybill 2012, 10], осмысливаемая как фронтирная, «островная» ментальность, противоречивая в своей основе. С одной стороны, сахадинская идентичность включает в себя подчинённость природе, неспешность жизни и систему ценностей, основанную на взаимопомощи и групповой солидарности. С другой стороны, эта «островная» идентичность порождает примеры асоциального с формальной точки зрения поведения человека, что исторически определяется в том числе «каторжной» историей освоения острова.

Культурно-географическое пространство острова оказалось органично вписанным в колониальный дискурс освоения отдалённых территорий империи. По аналогии с организацией английских, французских, испанских, португальских каторжных колоний в освоении Сахалина царское правительство использовало в качестве рабочей силы каторжных и ссыльных. Появление на Сахалине в 1858 г. экспериментальной партии каторжан (более 300 чел.) и активное передвижение ссыльных на остров привело к официальному объявлению в 1869 году Сахалина местом каторги и ссылки и прочным закреплением за островом наименования «каторжныци».

\footnotetext{
${ }^{1}$ По данным переписи населения 2010 года, в области проживало всего 498 тыс. человек, или 0,35 \% населения Российской Федерации. Русских было 430,8 тыс. человек, или 86,5\%; корейцев - 26,4 тыс. человек, или 5,3\%; украинцев - 13 тыс., или 2,6\%, а также около трёх тысяч представителей коренных народов, в том числе 2290 нивхов, 259 ульта (ороков).
} 
По воспоминаниям польского ссыльного и исследователя Сахалина Б. Пиясудского, в это время «само слово “Сахалин" вызывало дрожь ужаса у всех русских, его предпочитали произносить только шёпотом. Когда меня отправиди на этот прокдятый Богом остров в качестве политического ссыльного, я думал, что оказался в краю, где не оставалось ни надежд, ни шансов выбраться отсюда» [Пилсудский $2017,3]$. Писатель А. П. Чехов и публицист В. М. Дорошевич, отправившиеся в конце XIX века на Сахалин, совершая такое сложное путешествие в «мир невыносимых страданий», руководствовадись стремлением окунуться в «мир отверженных» и помочь им конкретным делом [Кудинова 1995, 14].

Ко времени поселения ссыльнокаторжных на острове Сахалине последний не был изучен. Те краткие исследования, которые были представлены командированными для этой цели дицами, касадись только общих представлений о флоре и фауне острова и некоторых его частных особенностях. Как отмечает В. М. Аатышев, именно регулярные рейсы пароходов Добровольного флота на Сахалин познакомили сотни дюдей, бывавших там по долгу службы, с каторжным островом. Но не красота природы, экзотика растительного и животного мира, удивительный мир аборигенов Сахалина (айнов, нивхов, ульта) запоминались прежде всего. Всё затмевади впечатления от каторги с её страшными и бесчеловечными порядками [Латышев 2002, 388]. В конце XIX века врач А. В. Поддубский писа о том, что «отдалённость каторги от центра, от бдительного надзора, редкость посещения людей, имеющих высшую власть, и краткость их пребывания на острове дают благоприятные условия для процветания произвола и корыстных стремлений на острове» [Поддубский 2004, 155]. Сахалин, таким образом, во многом открывался прибывшим на остров через призму «страданий» и «ужаса».

\section{Чеховский Сахалин в фотографиях конца XIX века}

В конце XIX века, вдохновлённые слухами и рассказами о Сахалине, в том числе о процветающей на нём каторге, огромную работу на острове проводят писатедь А. П. Чехов, публицист В. М. Дорошевич, врач Н. С. Лобас, зоолог П. Ю. Шмидт, доктор Н. В. Слюнин, юрист Н. Я. Новомбергский, горный инженер К. Н. Тульчинский, журналист Н. А. Панов и др. [Галлямова 2006]. Их работы, включающие обширный фактический материал, раскрывают вопросы сахалинской каторги и штрафной колонизации, особенности первоначаль- 
ного заселения острова, историю возникновения каторги и ссылки, развития горного дела, угольных и нефтяных месторождений, аграрного освоения, дают описание местных биоресурсов, морских промыслов и рыболовства.

Наряду с литературно-публицистическими и научными описаниями Сахалина распространяется также практика фотофиксации жизни острова, его природного и этнокультурного своеобразия. Если научные описания Сахалина тяготели к системности и организованности, то фотографические изображения предполагали наблюдательность и эмоциональную включённость в жизнь острова, сочетали миссионерски-просветительский, этнографический взгляд и туристическую оптику. Фотоснимки Сахалина порождали разновидность культурного мифа об освоении и приспособлении для жизни негостеприимного острова, а фотофиксация Сахалина сопровождалась публицистическо-литературным заказом на неё. Фотография в тот период, помимо прочего, выступала эффективным исследовательским ресурсом в познании фронтирных территорий, позволяла зафиксировать объективное и беспристрастное видение действительности, передать колорит эпохи. Природные объекты, предметы материальной культуры, человеческие образы, будучи запечатлёнными на фотоснимках, становились важными элементами конструирования образа территории, его визуализации в условиях дефицита письменных свидетельств.

Известна, к примеру, широкая популярность фотографического снимка известной преступницы - Соньки Золотой Ручки (ил. 1), которая отбывала каторгу на Сахалине и которая стала своеобразным символом этого острова. Журналист Панкратьев писал тогда о Соньке: «Каторга, от администрации до арестантов, гордилась Сонькой Золотой Ручкой. Сонька стала главной сахалинской достопримечательностью. Даже в одиночной камере, с кандалами на ногах, Соньке не давали покоя. Она сама вспоминала следующее только, бывает, успокоишься, снова требуют Соньку Золотую Ручку. Думаешь, что опять? Нет, фотографию снимать. Мучили меня этими фотографиями... то делалось по настоянию местного фотографа, сколотившего целое состояние на продажах фотокарточек Золотой Ручки. Соньку выводили на тюремный двор, устанавдивали декорацию - наковальни, кузнецы с молотами, надзиратели, и снимали якобы сцену заковывания Золотой Ручки в кандалы. Эти фотографии продавались сотнями на всех пароходах, приходивших на Сахалин. Особенной популярностью эти фотографии пользовалась в Европе» [Иванов 2010]. 


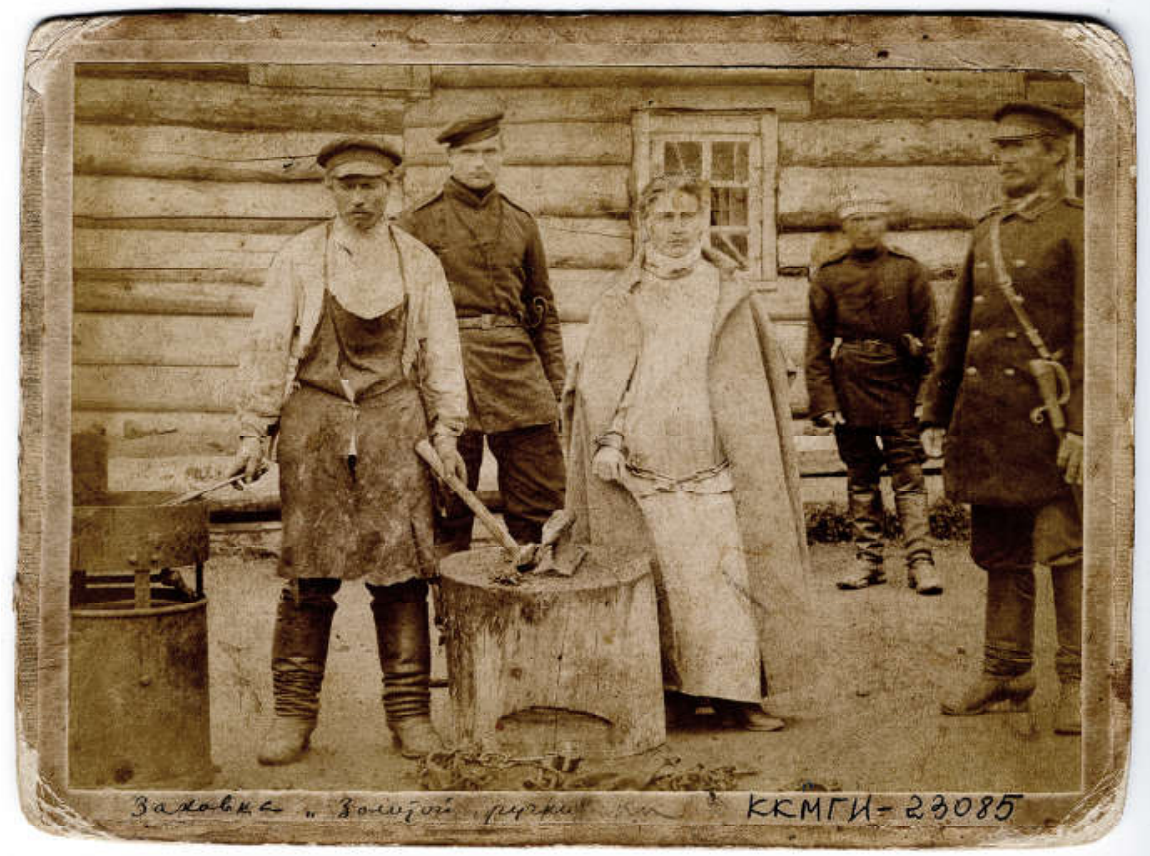

Ил. 1. Заковка Соньки Золотой Ручки в кандалы. Источник: Камчатский краевой объединённый музей

Как известно, поистине симптоматичным стало путешествие А. П. Чехова на Сахалин, чей труд «Остров Сахалин» оказался не просто литературным произведением, а одной из важных операций, сформировавших восприятие этого дальневосточного фронтира. Так, из 65 русских селений, обозначенных на карте Сахалина 1890 года, Антон Павлович описал или упомянул 54, а лично посетил 39 селений. Он в одиночку предпринял перепись ссыльнокаторжного населения, заполнив при этом около 10000 карточек, которые по специальному заказу писателя были напечатаны в небольшой типографии при местном полицейском управлении в посту Александровском. Со временем даже сложился устойчивый ассоциативный ряд: чеховский Сахалин - Сахалинский Чехов. Благодаря имени Чехова, его писательскому таланту остров Сахалин стал широко известен не только в России, но и за её пределами.

В наше время первое знакомство с далёким островом у многих также начинается с чтения книги А. П. Чехова «Остров Сахалин», обстоятельства создания которой, её композиционные и стидистические особенности доводьно хорошо исследованы в научной дитературе. Гораздо меньшее внимание обращается на тот факт, что 
А. П. Чехов стремился совместить свои описания Сахалина с визуальными, запечатлёнными на фотографиях образами острова. Чехов мечтал о том, чтобы первое издание книги «Остров Сахадин» непременно вышло с илдюстрациями и в письме к А. С. Суворину писал о том, что ему было бы приятно илдюстрировать свою книгу [Дунаева 1977, 263].

Известно, что А. П. Чехов начал своё путешествие на остров без фотографа. На Сахалине Антон Павлович познакомился с Иннокентием Игнатьевичем Павловским (родился в 1855), управляющим телеграфной станцией в поселении Дуэ. Павловский увлекался фотографией, выписывал из Японии и Америки самоучители, реактивы, пластины и достиг в мастерстве фотографии определённых успехов. Подтверждением высокой оценки его фотоснимков в профессионадьной среде является тот факт, что именно Павловскому была поручена подготовка фотоальбома в качестве подарка ожидавшемуся на Дальнем Востоке наследнику престола. Иннокентий Игнатьевич по просьбе Чехова фотографировал места, где побывал писатель.

По данным Е. Н. Дунаевой, общее количество фотографий Павловского, привезённых в 1890 г. Чеховым с Сахалина, было невелико, не более 6-7, и подборка их совершенно случайна, поскодьку Павловский выбирал технически лучшие, наиболее удавшиеся снимки [Дунаева 1977, 264]. В 1891 г. писатель получил новые фотоснимки от Павловского. В коллекции Чехова было также несколько фотографий, сделанных инспектором сельского хозяйства Сахадина Алексеем Алексеевичем фон Фрикеном в 90-х гг., а также фотографии судового врача парохода «Петербург» Александра Викторовича Щербака (1848-1894). Несколько снимков Сахалина были куплены Чеховым у фотографа В. В. Ланина, создававшего в конце XIX века антодогию видов и типов Восточной Сибири. Всего, согласно Е. Н. Дунаевой, фотоколлекция, связанная с поездкой Чехова на Сахалин и обратным плаванием, насчитывает 109 снимков и входит в состав Чеховского фонда Государственного литературного музея [Дунаева 1977, 266].

Фотографии Дальнего Востока (в том числе Сахалина) из частных фотоальбомов конца XIX века - одна из наиболее примечательных тем в современной визуальной антропологии, хотя по-прежнему часто остающаяся (в силу своей частности) за границами историографического и культуродогического дискурса. С одной стороны, фотоколлекции интересны именно тем, что они отражают мировоззрение, ценностные ориентации представителей запечатлённой 
на плёнку культуры. С другой стороны, фотоколлекции, репрезентирующие Дальний Восток России, оказываются востребованными в постсоветской ностальгии по дореволюционному прошлому. Выражаясь словами П. Нора, фотоархивы - это «бастионы памяти, раковины на берегу, с которого отхлынуло море живой памяти» [Nora 1989, 26]. Кроме того, фотографии из частных альбомов, касающиеся Сахадина, носят репортажный характер и представдяют собой значимый исторический источник, в котором запечатлена повседневная культура острова.

В состав таких фотоальбомов входят научно-документальные снимки, сделанные по заказу, во время экспедиций или путешествий, творческие и художественные снимки, репродукционные работы раздичной тематики. По технике исполнения большинство фотографий представляет собой альбуминовые отпечатки, выполненные на тонкой бумаге, покрытой эмульсией из смеси яичного белка, аррорута ${ }^{2}$ и соли, с использованием раствора нитрата серебра. Такой тип печати стал по-настоящему успешным и использовался с 1850-х годов вплоть до конца XX века [Максимова и др. 2013, 20].

Фотоматериал, с точки зрения метонимического подхода, - это носитель, материальное воплощение и символ памяти [Osborne 2000]. Что же считалось «достойным памяти» (memorable) об острове? Какие сюжеты и персонажи вкдючались в фотографический дискурс о Сахалине, какие эталоны выдвигались, как они могут быть упорядочены в соответствии с логикой изображения?

На наш взгляд, всю фотоколлекцию, посвящённую чеховскому Сахалину, можно разделить на несколько основных тематических групп:

1. Пейзажные съёмки и виды местностей Сахалина конца XIX века: снимки Александровского поста, Жонкиерского маяка, селений Ново-Михайловское и Красный Яр, поста Дуэ и его окрестностей, виды Корсаковского поста, Березников, Третьей пади, рудничной морской крепости общества «Сахалин». Фото И. И. Павдовского.

2. «Каторжные» сюжеты. Заковка в кандалы Золотой Ручки. Заковка в кандады и приковка к тачкам вновь прибывших арестантов (Дуйская тюрьма). Добыча угля. Вечерняя проверка арестантов (Воеводская тюрьма). Прикованные к тачкам. Арестанты за работой. Арестанты на полевых работах. Пересылка каторжных морским путём: прибытие арестантов по железной дороге, медицинский осмотр мужчин и женщин в канцелярии, погрузка на корабль, расковка арестантов, раздичные группы арестантов на палубе,

\footnotetext{
${ }^{2}$ Крахмальная мука из тропических растений.
} 
подготовка к спуску с корабля в одном из сахадинских портов. Фото И. И. Павловского и А. В. Щербака.

3. Этнографические фотоматериаль. Айно - родовой старшина из селения Тарайки (Южный Сахалин), айно из селения Найоро (Южный Сахалин), орок с восточного берега Сахалина, гиляк из селения Танги (Северный Сахалин), айно-гиляк из деревни Агнево близ поста Дуэ, оденные тунгусы. Фото И. И. Павдовского.

4. Бытовые сюжеть. Зимой на нартах. Переезд через реку. Японские рыбопромышленные суда в заливе Сиска на восточном берегу Сахалина, иконостас работы каторжных в церкви поста Александровский. Фото И. И. Павловского.

Отметим, что фотографии Сахалина, выполненные И. И. Павиовским, делятся на видовые и жанровые и соответствуют композиционной структуре книги «Остров Сахадин» А. П. Чехова, в первых главах которой, заканчивая четырнадцатой, даётся обзор населённых мест, а в последующих главах - «частности, важные и неважные, из которых в настоящее время слагается жизнь каторжан». При этом присутствует определённая корреляция фотографического и дитературного образа, каждая фотография, за немногими исключениями, может быть соотнесена с чеховским текстом и становится подлинной его илдюстрацией.

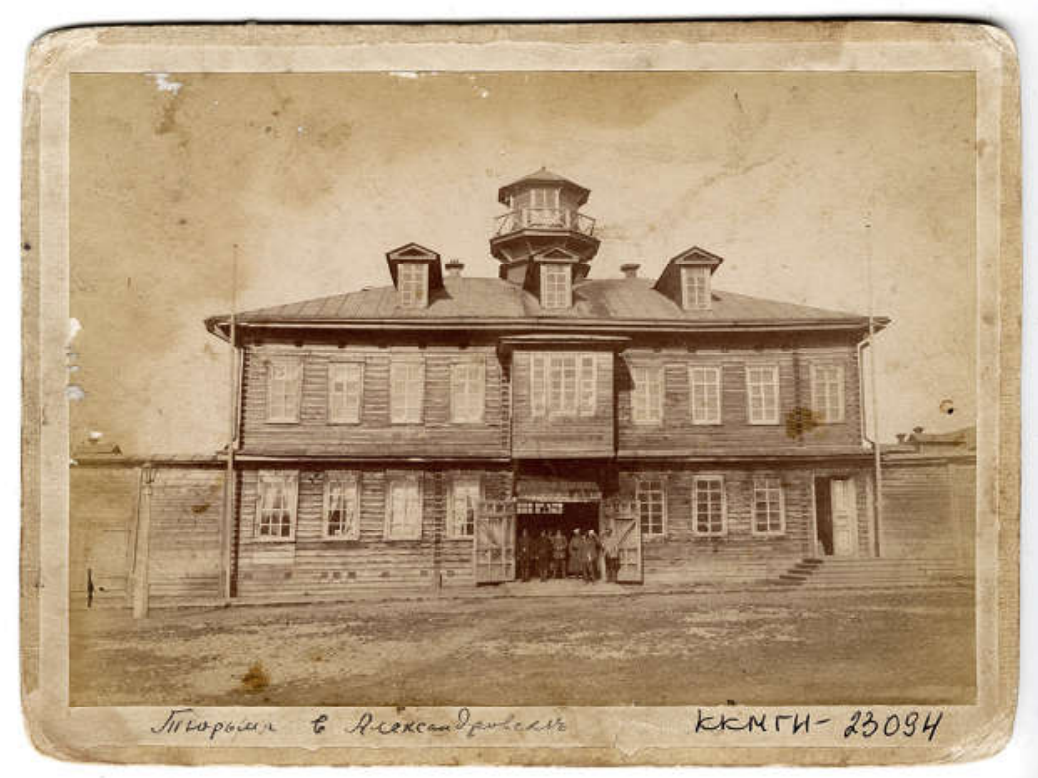

Ил. 2. Тюрьма в Александровске.

Источник: Камчатский краевой объединённый музей 
Так, фотоснимки Александровского поста (ил. 2, 3) буквально воспроизводят его иандшафт, описанный в «Острове Сахалине»: «Александровский пост, или, короче, Александровск, представляет из себя небольшой благообразный городок сибирского типа, тысячи на три жителей. В нём нет ни одной каменной постройки, а всё сделано из дерева, главным образом из диственницы: и церковь, и дома, и тротуары. Здесь резиденция начальника острова, центр сахалинской цивилизации. Тюрьма находится бдиз главной удицы, но по внешнему виду она мало отличается от военной казармы, и потому Александровск совсем не носит того мрачного острожного характера, какой я ожидал встретить» [Чехов 2011, 65].

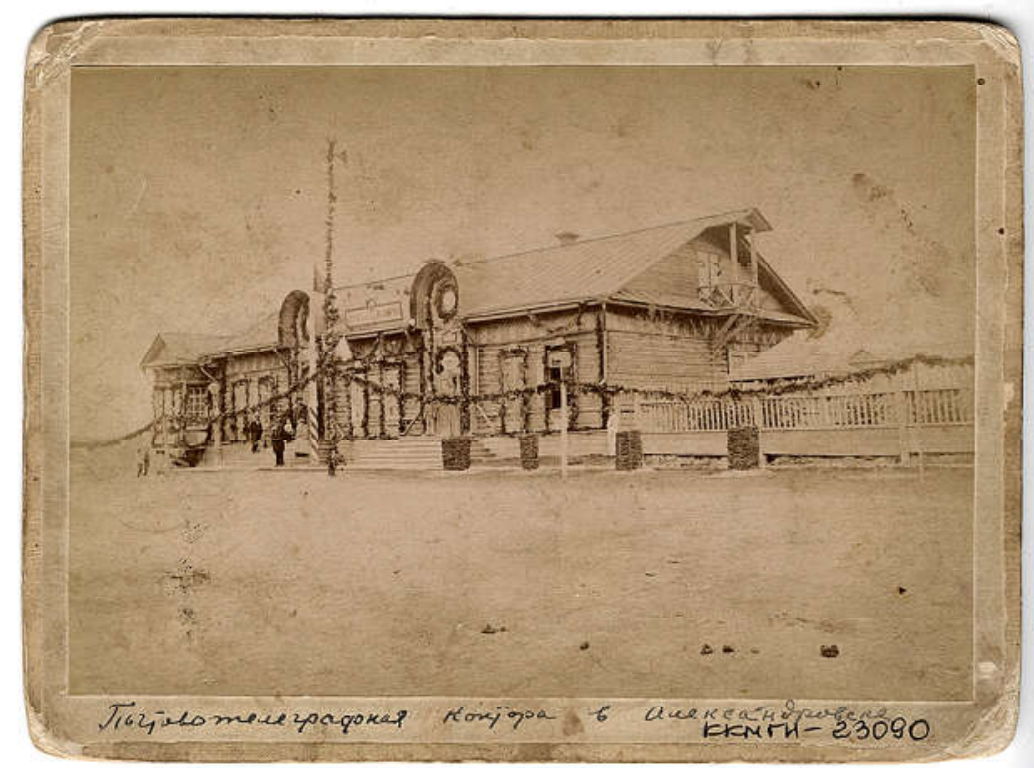

Ил. 3. Почтово-телеграфная контора в Александровске. Источник: Камчатский краевой объединённый музей

Фотографии, сделанные в период пребывания Чехова на Сахалине и объединённые в одну фотоколлекцию, имеют самое раздичное содержание: вместе с портретами, зафиксировавшими людей в фас, имеются образцы художественной портретной съёмки, жанровые сценки, снимки объектов материальной культуры, событий и пр. Фотограф помещает образ в контекст ландшафта, культуры Сахалина, сложившихся там социальных отношений и собственно персонального восприятия. При этом в фотоколлекции значительное внимание уделено именно антропологической съёмке, ссыльным 
и каторжанам, которые в то время были предметом большого общественного интереса. Очевидно, что бытовые сцены каторжан весьма интересовали Чехова, писавшего в письме Павловскому, что «к концу лета у меня будет до 100 экземпляров видов самых бытовых» [Дунаева 1977, 266].

Интерес к фотографированию каторжан очевидным образом соответствовал духу времени, в котором каторжники рассматривались как важнейшая социальная (а не только криминальная) проблема. Это проявлялось в первую очередь в активности разных исследователей, писателей, журналистов, побывавших на Сахалине, которые довольно часто обращадись к сценам из жизни каторжных и ссыльных. В их фотографическом изображении сцены непосредственной фиксации рабочих будней каторжан соседствуют с абсолютной инсценированностью (как в случае портретных групповых фотоснимков). И. И. Павдовский называл такие снимки «деланными», поскольку они передавали напряжение и искусственность поз дюдей, не желавших фотографироваться и чувствовавших подозрительное отношение «островного» начальства к работам фотографов [Дунаева 1977, 267].

Отметим, что фиксация быта на острове мысдилась именно как съёмка чедовека в культурном контексте, как представдение материально-духовной стороны через его носителя. При выборе лица для снятия портрета фотографы, снимавшие Сахалин, руководствовались типичностью персонажей, понимая под этим дица, которые в данном месте встречаются чаще других. Чедовек с его индивидуальной жизненной историей (коренной житель края, ссыльный, каторжник) оказывался удобным объектом классификации, упорядочивания. Одежда изображённых на снимках персонажей указывала на их социальную роль, идейное и эстетическое содержание, а вещи (предметы труда и быта каторжников и ссыльных) рассматривадись в качестве визуальных признаков принадлежности к группе.

\section{Заключение}

По всей видимости, фотографические и литературные образы чеховского Сахалина, выстраивающие визуальную «аутентичность экзотики» острова, оказали сильное воздействие на воображение современников. Места и виды Сахалина, отражённые на фотоснимках, предназначались для повторного посещения/потребления. 
Известен факт, когда впечатлённый чеховским творением о Сахалине на остров в 1897 г. отправляется газетный писатель, публицист Влас Михайлович Дорошевич (1865-1922), который проделал путешествие до острова на «каторжном» пароходе «Ярослав $и$ »» из Одессы и специально для путешествия выучился фотографическому искусству [Букчин 2010, 159-162]. Итогом первой поездки Дорошевича на Сахалин (вторая случилась в 1902 году) стали сенсационные очерки о каторге, объединённые затем в известную книгу «Остров Сахалин. Каторга», илдюстрированные фотографиями каторжного быта Сахалина конца XIX века. Это были своеобразные визуальные послания («визуальная грамматика»), запущенные в элитарную и массовую культуру конца XIX - начала XX вв., которые надолго поселялись в научных публикациях и исподьзовадись издателями как объективные свидетельства. В условиях трансформации памяти о локадьных местах в постпамять (postmemory) [Hirsh 1997] фотографические виды чеховского Сахалина очевидным образом продолжают и сегодня активно формировать представления об этом острове.

Выбирая событие для съёмки, негатив дия печати и снимок для фотоальбома, фотограф вольно или невольно задаёт границы пространства воспоминаний, возникающих при просмотре фотографий. Судя по сохранившимся фотографиям Сахалина конца XIX века, визуальные критерии жизни на «каторжным острове» создавадись посредством построения типических персонажных позиций и жанровых сцен (труд и быт каторжан), физической антропологии («инородческие дица», «дица преступников»), архитектурного и природного иандшафта острова, определялись режимом просмотра «картинки» или фотоальбома.

Несмотря на то, что, по словам Д. Бергер, любая фотоколдекция - это всегда «след чьего-то решения вырвать и сохранить один момент из милдиона других» [Berger 1980, 292], фотографии воспринимадись как неоспоримое доказательство существования «каторжного острова», принадлежности Сахалина к России. Фотоснимки Сахалина, наряду с литературными опытами конца XIX века, проводили зримые границы между населением острова и остальной Россией и, зафиксировав их, утверждали наличие у сахалинского сообщества стабильных отличительных признаков. В этом смысле можно говорить о том, что фотографии чеховского Сахалина не в меньшей степени, чем литература, фиксировали «визуальные очевидности», активно конструируя их в общественном сознании. 


\section{БИБЛИОГРАФИЯ}

Арсеньев 1920 - Арсеньев В. К. Обзорная статья «Подожение Дальневосточного края и границы» (1920-е гг.) // Архив Общества изучения Амурского края (АОИАК). Ф. 14. Оп. 1. Д. 49.

Арсеньев 1926 - Арсеньев В. К. Справка в Полномочное представительство объединённого государственного политического управления Дальним Востоком о хищническом отношении Америки, Японии, Китая и Кореи к народам Дальнего Востока. 4 ноября 1926 // Архив Общества изучения Амурского края (АОИАК). Ф. 14. Оп. 1. Д. 56.

Букчин 2010 - Букчин С. В. Влас Дорошевич. Судьба фельетониста. Москва, 2010.

Вишленкова 2011 - Вишленкова Е. А. Визуальное народоведение империи, иди «Увидеть русского дано не каждому». Москва, 2011.

Галлямова 2006 - Галлямова И. И. Освоение Сахалина в оценке российских исследователей второй половины XIX - начала XX века // Вестник Дальневосточного отделения Российской академии наук. 2006. № 3. C. 156-162.

Головнева 2018 - Головнева Е. В. Конструирование региональной идентичности в современной культуре (на материале Сибирского региона). Диссертация на соискание учёной степени доктора философских наук. Екатеринбург, 2018.

Дунаева 1977 - Дунаева Е. Н. К истории работы над книгой «Остров Сахалин» // Дитературное наследство. 1977. Т. 87. С. 263-300.

Иванов 2010 - Иванов А. Остров несводобы. Почему провадидся сахалинский эксперимент по очеловечиванию преступников // Svpressa.ru. 19 сентября 2010. [Электронный ресурс]. Режим доступа: https://svpressa.ru/society/article/30645/ (дата обращения: 27.06.2019).

Кудинова 1995 - Кудинова Е. П. А. П. Чехов и В. М. Дорошевич: личные контакты, проблемы творческих связей на материале произведений о Сахадине. Диссертация на соискание учёной степени кандидата филологических наук. Балашов, 1995.

Датышев 2002 - Датышев В. М. Через Сахадинчик на Сахадин // Вестник Сахалинского музея. 2002. № 1 (9). С. 382-390.

Максимова и др. 2013 - Идентификация, хранение и консервация фотоотпечатков, выполненных в раздичных техниках / Сост. А. В. Максимова, К. А. Мисюра-Аладова, Ю. А. Богданова. Санкт-Петербург, 2013. 
Пилсудский 2017 - Пилсудский Б. Гиляки и их песни // Этнографические записки Сахалинского областного краеведческого музея. № 1. Южно-Сахалинск, 2017. С. 3-13.

Поддубский 2004 - Подуубский Л. В. Заметки о Сахадинской каторге и ссылке // Вестник Сахалинского музея. 2004. № 1 (11). С. 149 158.

Смирнов 2017 - Смирнов С. А. Визуальное путешествие как метод. Генезис // ПРАЕНМА. Проблемы визуальной семиотики. 2017. № 1 (11). C. 9-26.

Чехов 2011 - Чехов А. П. Из Сибири. Остров Сахалин. Москва, 2011. Berger 1980 - Berger J. Understanding a photograph // Classic Essays on Photography. Ed. by Alan Trachtenberg. New Haven (CT), 1980. P. 291-294.

Cosgrove 2008 - Cosgrove D. Geography and Vision: Seeing, Imagining, and Representing the World. London, 2008.

Graybill 2013 - Graybill J. K. Mapping an Emotional Topography of an Ecological Homeland: The Case of Sakhalin Island, Russia // Emotions, space and society. 2013. Vol. 8. P. 39-50.

Hirsh 1997 - Hirsh M. Family frames: Photography, Narrative and Postmemory. Cambridge (MA), 1997.

Jay 1988 - Jay M. Scopic Regimes of Modernity // Vision and Visuality. Ed. by Hal Foster. Seattle, 1988. P. 3-28.

Kearney, Kaplan 1997 - Kearney A., Kaplan S. Toward a Methodology for the Measurement of Knowledge Structures of Ordinary People: The Conceptional Content Cognitive Map // Environment and Behavior. 1997. 29 (5). P. 579-617.

Kivelson, Neuberger 2008 - Picturing Russia: Explorations in Visual Culture. Ed. by V. Kivelson, J. Neuberger. New Haven (CT), 2008. Matsuzato 2007 - Imperiology: From Empirical Knowledge to Discussing the Russian Empire. Ed by K. Matsuzato. Sapporo, 2007.

Nora 1989 - Nora P. Between Memory and History: Les Lieux de Mémoire // Representations. 1989. 26. P. 7-24.

Osborne 2000 - Osborne P. D. Travelling Light: Photography, Travel, and Visual Culture. Manchester, 2000. 